\title{
Acute hypotensive and diuretic activities of Berberis vulgaris root bark aqueous extract in normal rats
}

\author{
Muhammad Ahmed, ", Aisha Azmat², Salahuddin Khan³ \\ ${ }^{1}$ Department of Pharmacology, Faculty of Pharmacy, Umm Al-Qura University, Makkah, Saudi Arabia, ${ }^{2}$ Department of \\ Physiology, Faculty of Medicine, Umm Al-Qura University, Makkah, Saudi Arabia, ${ }^{3}$ Department of Biochemistry, College of \\ Medicine, Al-Imam Mohammad Bin Saud Islamic University, Riyadh. KSA
}

\begin{abstract}
The aim of this study is to investigate the effectiveness of intravenous administration of Berberis vulgaris root bark aqueous extract (BRBD) on the cardiovascular and renal functions of healthy normotensive rats. The different doses of BRBD 1, 10 and $20 \mathrm{mg} / \mathrm{kg}$ were administered intravenously (i.v) in normal rats. Blood pressure, diuretic activity and serum renal profile were analyzed. Intravenous injection of BRBD at the different doses of 1,10 and $20 \mathrm{mg} / \mathrm{kg}$ showed a dose-dependent reduction in mean arterial blood pressure $(\mathrm{P}<0.001)$. At different doses of 1,10 and $20 \mathrm{mg} / \mathrm{kg}$, the hypotensive effect remained for more than one hour. Single dose administration of BRBD at doses of 10 and $20 \mathrm{mg} / \mathrm{kg}$ caused a significant increase in urine output $(\mathrm{P}<0.001)$ as compared to the control rats. Serum renal profile test (albumin, Urea, Uric Acid, creatinine and BUN) did not show any significant alteration. The authors conclude that the BRBD is a potent hypotensive and possesses diuretic potential
\end{abstract}

Keywords: Berberis vulgaris root bark/ aqueous extract (BRBD). Mean arterial blood pressure (MABP). Diuresis. Serum renal profile test

\section{INTRODUCTION}

Since ancient times, numerous species of plant have been used in folkloric medicine to manage different ailments due to their medicinal properties. The World Health Organization claims that more than $80 \%$ of the world's population confide in plants and plant-based herbal medicines for healthcare (Gurib-Fakim, 2006). In the list of non-communicable diseases, the management of cardiovascular diseases, especially hypertension, without any side effects is still a hard task for health professionals. For that reason, research on medicinal plants (for the management of cardiovascular disorders) has become a necessity nowadays. Different plants and their extracts reported for their hypotensive activity include Artemisia herba alba (Zeggwagh, Michel, Eddouks, 2014), Tropaeolum majus L (Gasparotto et al., 2011), Berberis orthobotrys Bien Ex Aitch (Alamgeer et al., 2013), Hibiscus sabdariffa L. (Allison et al., 2013),

\footnotetext{
*Correspondence: M. Ahmed. Department of Pharmacology, Faculty of Pharmacy, Umm Al Qura University, Al Abidiya Taif Road. PO Box No.13578 - Makkah Al Mukarrama, Kingdom Of Saudi Arabia. E-mail: Hma00ahmed@hotmail.com / mmsiddiqui@uqu.edu.sa
}

Berberis vulgaris (Azmat et al., 2009) and Moringa stenopetala (Baker f.) Cufod. Leaves (Geleta et al., 2016). For the treatment of cardiovascular disorders especially hypertension, different antihypertensive therapies are used with diuretics (Zeggwagh, Michel, Eddouks, 2014). For this management, the economic impact of hypertension is enormous because cost-effective antihypertensive medicine with diuretic potentials is currently unavailable. Earlier studies have reported the diuretic effect of several plant extracts on normal and hypertensive rats (Amonkan et al., 2013; Hernández-Luis et al., 2014). Furthermore, the observed diuretic activity was associated in several cases with a reduction in arterial blood pressure (Kazama et al., 2012). Taking in consideration these prospects, the present study was planned to observe the Acute Hypotensive and Diuretic Activities of Berberis vulgaris Root Bark Aqueous Extract in Normal Rats.

\section{MATERIAL AND METHODS}

\section{Plant}

The roots bark of $B$. vulgaris $L$. is dark brown and soft. The root bark in powdered form is a dark brown color. The 
roots of B. vulgaris were collected from the Gilgit-Baltistan region (Khan, Khan, Rehman, 2014) in Pakistan in June 2003 and transported safely to Karachi, Pakistan. The root bark was then separated from the root pulp in the research lab with the help of a sharp garden knife, and the bark was powdered in a mill.

\section{Extraction (Preparation of Decoction)}

BRBD was prepared by boiling the root bark powder in distilled water for ten minutes, then cooling it for fifteen minutes and filtering. For the preparation of the decoction, $100 \mathrm{mg}$ root bark powder was boiled with $10 \mathrm{ml}$ of distilled water for ten minutes and later it was considered that $\begin{array}{ll}100 \mathrm{mg} & 10 \mathrm{~mL} \\ 10 \mathrm{mg} & 1 \mathrm{~mL} \\ 1 \mathrm{mg} & 0.1 \mathrm{~mL}\end{array}$

A freshly prepared decoction was used to test for hypotensive and diuretic activity.

\section{Animals}

Rats (Sprague Dawley: 220 to 240 g) were selected from Dr. Hafiz Muhammad Ilyas Institute of Pharmacology and Herbal Sciences (Dr. HMIIPHS) 6 days before experimentation and kept in optimal conditions (food and tap water ad libitum: $12 \mathrm{~h}$ light/dark cycle). The experimental procedures were performed according to the Guidelines for Care and Use of Laboratory Animals (National Research Council, 2011). All experimental procedures were approved by a review board of the departmental research committee.

\section{Chemicals and drugs}

In the present study, the following drugs were used.

\begin{tabular}{lll}
\hline $\begin{array}{l}\text { Acetylcholine } \\
\left(10^{-6}\right)\end{array}$ & $\begin{array}{l}\text { E. Merck } \\
\text { (Germany) }\end{array}$ & positive control \\
\hline $\begin{array}{l}\text { Sodium chloride } \\
(0.9 \%)\end{array}$ & $\begin{array}{l}\text { E. Merck } \\
\text { (Germany) }\end{array}$ & negative control \\
\hline Heparin & $\begin{array}{l}\text { Leo } \\
\text { Pharmaceutical } \\
\text { (Denmark) }\end{array}$ & anticoagulant \\
\hline $\begin{array}{ll}\text { Pentothal } \\
\text { sodium }\end{array}$ & $\begin{array}{l}\text { Abbott Karachi } \\
\text { (Pakistan) }\end{array}$ & anesthetic agent \\
\hline
\end{tabular}

\section{Hypotensive activity}

Just prior to the experiment for the measurement of mean arterial blood pressure (MABP), Pentothal sodium (40 mg/kg i.p.: Azmat, Ahmed, 2014) was used as the anesthetic. First, the trachea and external jugular vein both were both cannulated for smooth respiration (Feng et al., 2015) and intravenous drug administration. The arterial blood pressure (ABP) was monitored from the carotid artery via a heparinized tube connected to a transducer (Harvard, 60 to 3003). During experimentation, body temperature was controlled at $37^{\circ} \mathrm{C}$ by using the overhanging lamp.

Mean arterial blood pressure (MABP) was determined as $\mathrm{DBP}+1 / 3$ Pulse pressure or pulse width (Adeboye et al., 1999). Any variation in blood pressure (BP) was noted as a percent of control values (Azmat et al., 2009). Acetylcholine (ACh: positive control) was used to check the normal cardiac functions. A single dose of ACh $\left(10^{-6}\right)$ caused $47.61 \pm 3.31 \%($ mean \pm SEM, $n=6)$ drop in MABP. The hypotensive studies were performed on different doses of BRBD.

\section{Diuretic activity}

The three groups of rats (each with six rats) were used in this study to measure diuretic activity. The rats were catheterized as described earlier.

The first group of six rats served as control (saline solution, $0.9 \%$ ), whereas the second and third groups received i.v. BRBD, 10 and $20 \mathrm{mg} / \mathrm{kg}$ respectively. The experimental phase for each rat was $4 \mathrm{~h}$. During this 4hour period, excreted urine samples were collected and measured.

\section{Biochemical estimation (Renal Profile)}

At the end of 4 hours the samples of blood (5 to $8 \mathrm{~mL}$ ) were collected from the jugular vein, and were used for the detection of different parameters:

\begin{tabular}{ll}
\hline Serum Total Protein & $\begin{array}{l}\text { Ecoline } \\
\text { method } S+\text { by biuret }\end{array}$ \\
\hline Albumin & $\begin{array}{l}\text { Ecoline }{ }^{\circledR} \mathrm{S}+100 \text { by } \\
\text { bromocresol green method }\end{array}$ \\
\hline Urea & $\begin{array}{l}\text { Ecoline }{ }^{\circledR} 100 \text { by UV test, } \\
\text { GIDH method }\end{array}$ \\
\hline Uric Acid & Ecoline ${ }^{\circledR} 100$ \\
\hline Blood Urea Nitrogen & Ecoline ${ }^{\circledR} 100$ by UV test, \\
(BUN) & GIDH method \\
\hline Creatinine & $\begin{array}{l}\text { Ecoline }{ }^{\circledR} S+\text { by Jaffe } \\
\text { method }\end{array}$ \\
\hline
\end{tabular}




\section{Statistical analysis}

Variation in blood pressure and serum level of renal profile after i.v administration of BRBD was analyzed by using student's t-test. Values of $\mathrm{P}<0.05$ were considered to be significant.

\section{RESULTS}

\section{Effect of various doses of BRBD on various blood pressure parameters}

The results regarding the intravenous administration of BRBD on various blood pressure parameters are shown in Figure 1. Three different doses of BRBD initiated an immediate significant reduction in MABP (Figure 1). The maximal reduction was observed at the dose of $20 \mathrm{mg} / \mathrm{kg}$ $(\mathrm{P}<0.001)$. This observed reduction in MABP remained for more than one hour and returned to baseline after $106 \pm 12.36 \mathrm{~min}$ and $193 \pm 13.94 \mathrm{~min}$ at $10 \mathrm{mg} / \mathrm{kg}$ and $20 \mathrm{mg} / \mathrm{kg}$ BRBD respectively. However, in the negative control group, the saline administration did not the affect arterial blood pressure. On the other hand, ACh $\left(10^{-6}\right)$ caused a $46 \%$ fall in MABP, but it returned to baseline after $35 \pm 5 \mathrm{~s}$.

\section{Diuretic activity}

\section{Effect on urine volume}

Results of diuretic activity are shown in Fig. 2. Intravenous administration of BRBD $(10 \mathrm{mg} / \mathrm{kg})$ showed marked diuresis during the $4 \mathrm{~h}$ of the test $(B R B D$
$2.961 \pm 0.436 \mathrm{~mL}$ versus control $1.52 \pm 0.681 \mathrm{~mL} ; \mathrm{P}<0.05)$. At the dose of $20 \mathrm{mg} / \mathrm{kg}, \mathrm{BRBD}$ also showed marked diuresis during the $4 \mathrm{~h}$ of the test (BRBD $5.361 \pm 0.23 \mathrm{~mL}$ versus control $1.52 \pm 0.681 \mathrm{~mL} ; \mathrm{P}<0.05)$.

\section{Effect of BRBD on serum renal profile}

Non-significant changes in the serum total protein, albumin, urea, uric acid, creatinine and BUN were monitored in the BRBD $(10 \mathrm{mg} / \mathrm{kg})$, intravenous treated rats in comparison to their respective control rats.

\section{DISCUSSION}

Berberis is widely used in folkloric medicine to treat various ailments (Javadzadeh, Ebrahimi, 2013). This study assessed the hypotensive and diuretic effects of intravenous injection of aqueous Berberis vulgaris root bark extract on normal rats at the doses of 1,10 and $20 \mathrm{mg} / \mathrm{kg}$, and arterial blood pressure was recorded through a catheter implanted in the carotid artery. Usually, this method is used for blood pressure measurement to screen the effect of drugs on the cardiovascular system (Kurtz et al., 2005). The results demonstrated that i.v administration of BRBD showed an immediate and significant decrease in mean arterial blood pressure (MABP). Our findings are in agreement with the previous finding that ethanolic and methanolic extract of B. vulgaris root pulp possesses hypotensive activity (Azmat et al., 2009). Another study also revealed that extract of barberry root reduced the blood pressure in cats for several hours (Javadzadeh, Ebrahimi, 2013). In our present study, the hypotensive effect persisted

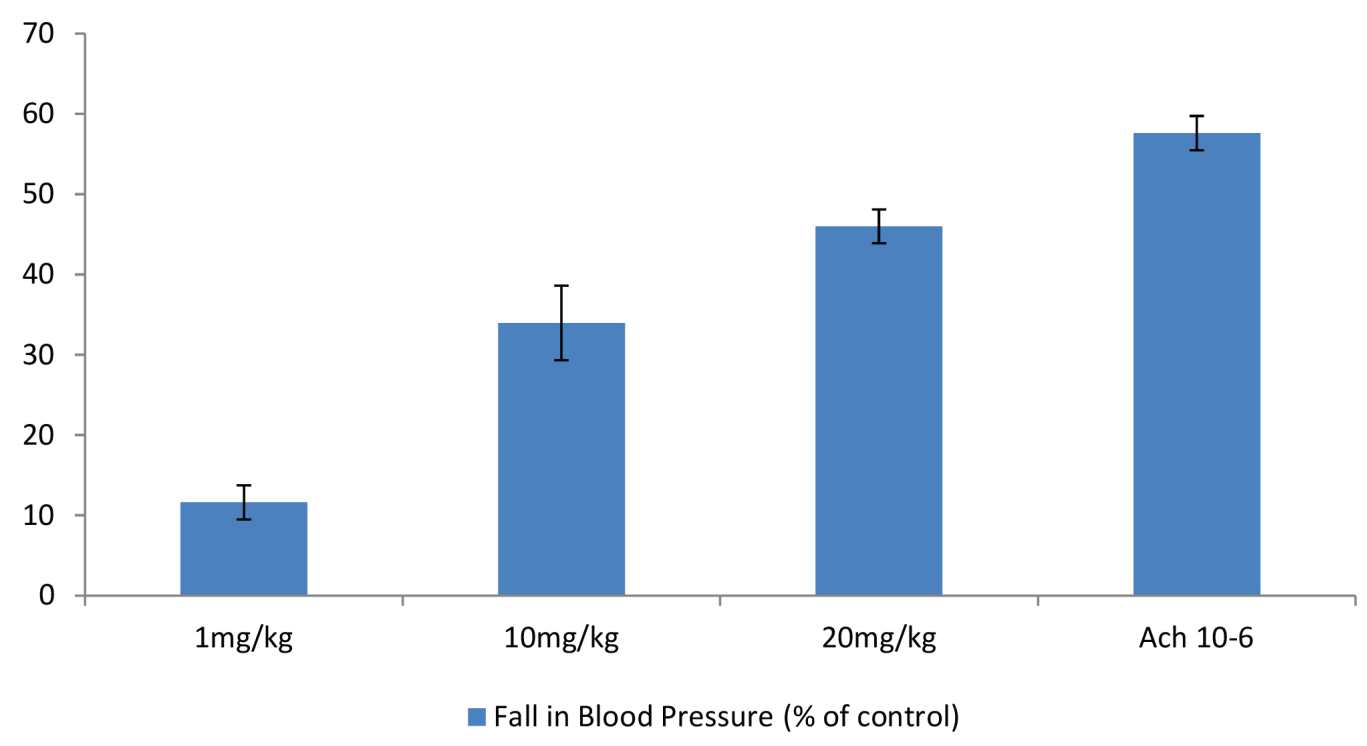

FIGURE 1 - Hypotensive activity of BRBD in normotensive rats. 


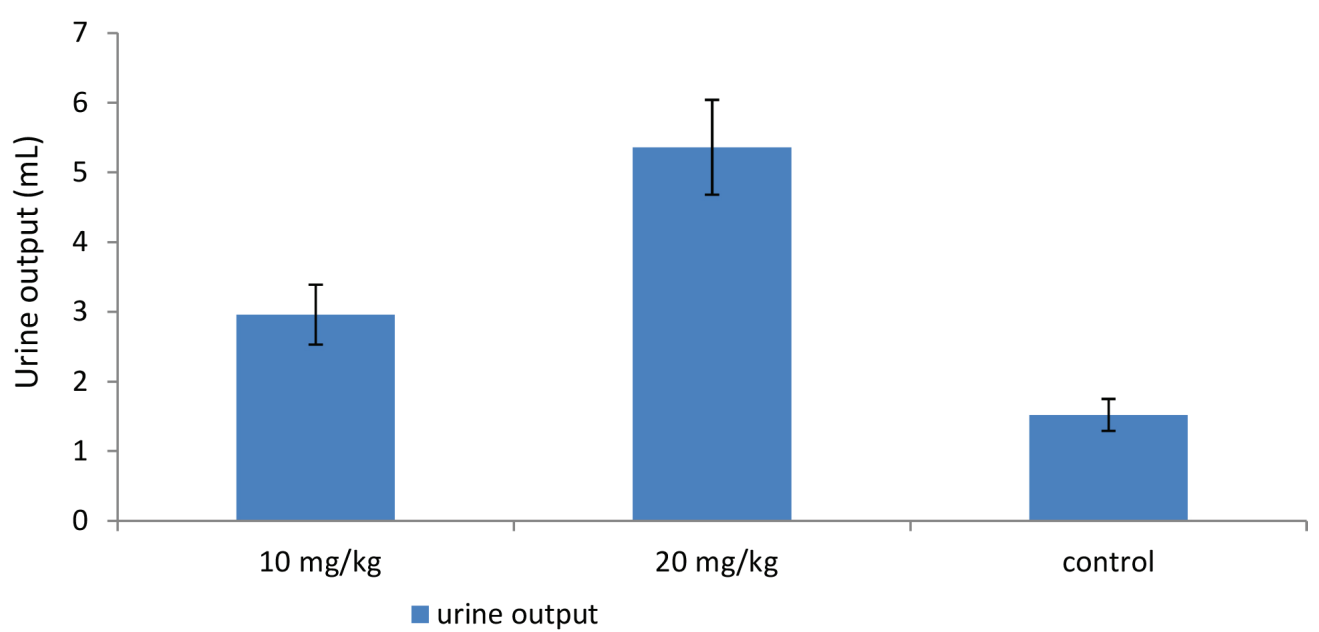

FIGURE 2 - Diuretic activity of BRBD in rats.

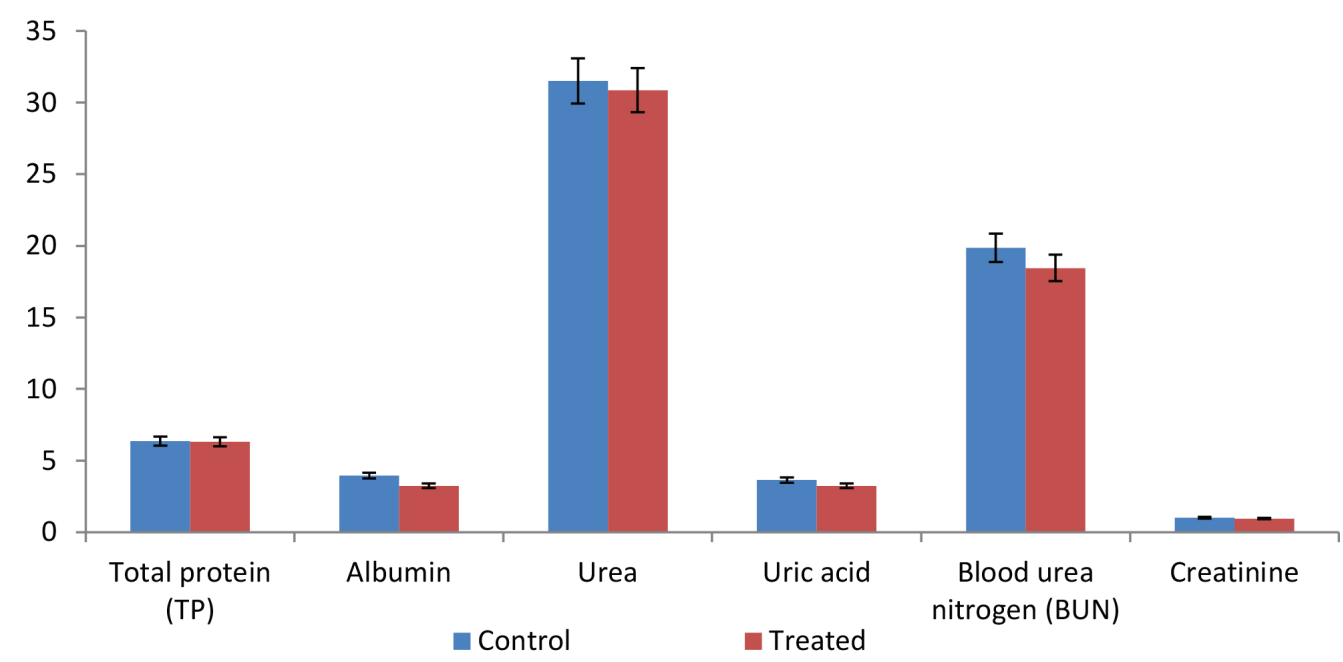

FIGURE 3 - Effect of BRBD (20mg/kg) on Serum Renal Profile.

for an extended period. Different studies proposed a different mechanism of action, suggesting that Berberine increased contractile force, decreased peripheral vascular resistance and lowered blood pressure (Lau et al., 2001; Shen, 1997; Harvey, 2012). For diuretic activity, BRBD was administered intravenously (10 and $20 \mathrm{mg} / \mathrm{kg}$ ) and Urine volume was measured to assess the renal effect of BRBD. The results demonstrated that BRBD extract increased diuresis significantly. Earlier research has shown that the presence of organic acids in barberry is responsible for the diuretic activity of medicinal plants (Javadzadeh, Ebrahimi, 2013). Serum renal profile showed non-significant changes in serum albumin, total protein, uric acid, urea, blood urea nitrogen (BUN) and creatinine level indicating nephroprotective effects. It is concluded that the BRBD possesses a dose-dependent hypotensive and diuretic effect upon i.v administration in rats.

\section{REFERENCES}

Adeboye JO, Fajonyomi MO, Makinde JM, Taiwo OB. A preliminary study on the hypotensive activity of Persea Americana leaf extracts in anaesthetized normotensive rats. Fitoterapia. 1999; 70(1):15-20.

Alamgeer, Muhamamd SA, Jabeen Q, Akram M, Khan HU, Karim S, Malik MNH, Mushtaq MN, Salma U. Antihypertensive activity of aqueous-methanol extract of berberis orthobotrys bien ex aitch in rats. Tropical J Pharm Res. 2013;12(3):393-399.

Allison L, Hopkins MG, Lamm JL, Cheryl RF. Hibiscus sabdariffa $L$. in the treatment of hypertension and hyperlipidemia: A comprehensive review of animal and human studies. Fitoterapia. 2013;85:84-94. 
Amonkan AK, Konan AB, Ahui BM, Bleyéré MN, Kouakou LK, Bouafou GM. Diuretic effects of aqueous extract of Ficus exasperata Vahl. leaves in rat. Pak J Biol Sci. 2013;16(21):13831387.

Azmat A, Ahmed M, Zafar N, Ahmad SI. Hypotensive activity of methanolic extract of berberis vulgaris (Root pulp and Bark). Pak J Pharmacol. 2009;26(2):41-47.

Azmat A, Ahmed M. Hypotensive activity, toxicology and histopathology of different extracts of Berberis vulgaris. J Med Plant Res. 2014;8(8):378-85.

Feng J, Fitz Y, Li Y, Fernandez M, Cortes PI, Wang D. Catheterization of the carotid artery and jugular vein to perform hemodynamic measures, infusions and blood sampling in a conscious rat model. J Vis Exp. 2015;(95):51881.

Gasparotto JA, Gasparotto FM, Lourenço EL, Crestani S, Stefanello ME, Salvador MJ, da Silva-Santos JE, Marques MC, Kassuya CA. Antihypertensive effects of isoquercitrin and extracts from Tropaeolum majus L.: evidence for the inhibition of angiotensin converting enzyme. J Ethnopharmacol. 2011;134(2):363-372.

Geleta B, Makonnen E, Debella A, Tadele A. In vivo antihypertensive and antihyperlipidemic effects of the crude extracts and fractions of moringa stenopetala (Baker f.) cufod. Leaves in Rats. Frontiers Pharmacol. 2016;7:97.

Gurib-Fakim A. Medicinal plants: traditions of yesterday and drugs of tomorrow. Mol Aspects Med. 2006;27(1):1-93

Harvey RD. Muscarinic Receptor Agonists and Antagonists: Effects on cardiovascular function. In: Fryer AD, Christopoulos A, Nathanson NM, editors. Muscarinic receptors, handbook of experimental pharmacology 208. Berlin, Heidelberg: SpringerVerlag; 2012.

Hernández-Luis F, Abdala S, Dévora S, Benjumea D, MartínHerrera D. Electrical conductivity measurements of urine as a new simplified method to evaluate the diuretic activity of medicinal plants. J Ethnopharmaco. 2014;151(2):1019-1022.
Javadzadeh SM, Ebrahimi A. The traditional uses and pharmacological effects of different parts Berberis Vulgaris (berberine). Iran Sci Agri. 2013;1(2):61-66

Kazama CC, DT Uchida, KN Canzi, P de Souza, S Crestani, A Gasparotto Jr, Laverde AJR. Involvement of arginine-vasopressin in the diuretic and hypotensive effects of Pereskia grandifolia Haw. (Cactaceae). J Ethnopharmacol. 2012;144(1):86-93.

Khan T, Khan IA, Rehman A. A review on Berberis species reported from Gilgit Baltistan and Central Karakoram National Park, Pakistan. J Med Plants Studies. 2014;2(6):16-20

Kurtz TW, Griffin KA, Bidani AK, Davisson RL, Hall JE. Subcommittee of Professional and Public Education of the American Heart Association Council on High Blood Pressure Research. Recommendations for blood pressure measurement in humans and experimental animals: part 2: blood pressure measurement in experimental animals: a statement for professionals from the Subcommittee of Professional and Public Education of the American Heart Association Council on High Blood Pressure Research. Arterioscler Thromb Vasc Biol. 2005;25:e22-e33.

Lau CW, Yao XQ, Chen ZY, Ko WH, Huang Y. Cardiovascular actions of berberine. Cardiovasc Drug Rev. 2001;19(3):234-44.

National Research Council. Guide for the care and use of laboratory animals. 8th. Ed. Washington: The National Academies Press; 2011. Available at: http://grants.nih.gov/ grants/olaw/Guide-for-the-care-and-use-of-laboratory-animals. pdf.

Shen YJ. Chinase pharmacology. Shanghai: Science and Technology Publishing Company; 1997, p. 50-52.

Zeggwagh NA, Michel JB, Eddouks M. Acute hypotensive and diuretic activities of Artemisia herba alba aqueous extract in normal rats. Asian Pacific J Tropical Biomed. 2014;4(2):S644-S648.

Received for publication on $15^{\text {th }}$ February 2017 Accepted for publication on $06^{\text {th }}$ April 2017 